\title{
EVALUATION OF LOGGER PRO INNOVATIVE TECHNOLOGY SUPPORTED APPLICATIONS IN THE SCOPE OF STEM
}

PROBLEMS

OF EDUCATION

IN THE $21^{\text {st }}$ CENTURY

Vol. 79, No. 5, 2021

751

\author{
Ahmet Kumas \\ Uşak University, Turkey \\ E-mail: ahmetkumas_61@hotmail.com
}

\begin{abstract}
Although advanced technological tools and equipment are used effectively in daily life, the inability of all students to access high-tech experiment applications in high schools negatively affects disadvantaged student groups in the further education process. The main purpose of the research evaluates students in four different categories about 10th-grade illuminance subjects by using Logger Pro technology within the scope of STEM. The study was carried out with 84 students at the school where the researcher taught in the fall semester of the 2019-2020 academic year. Within the scope of action research, qualitative and quantitative methods were used together. Quantitative findings were evaluated with SPSS and qualitative findings were evaluated with content analysis. Based on the research findings, it is revealed that the use of experimental content supported by innovative technology within the scope of science in high schools make a significant contribution in three categories within the scope of hopes and goals for STEM. Making applications supported by Logger Pro with technological content in schools improves the responsibilities of students in homework, contributes to their successful graduation from high schools and enables them to get into the departments they want in the university. These practices cause students to enjoy the professions they will choose in the future and help them reach their favorite professions by working harder.
\end{abstract}

Keywords: experimental content, innovative technology, physics teaching, STEM

\section{Introduction}

Science courses in coordination with the development of technology; knowledge, comprehension, problem-solving, scientific method process consists of learning systematics. Within the scope of science which has a dynamic learning systematic; in order for science and technology, physics, chemistry and biology courses to be presented effectively and qualified to the students, practitioners must have new and open-to-change application skills, use scientific methodology in their applications and support the information they present with innovative methods based on innovative technology (Linn, 2003). Considering that the content of science courses is dynamically effective in every part of life, it becomes clear that the content of science courses cannot be successfully presented without performing experimental applications that reflect the context and events in daily life (Aydoğdu et al., 2013; Camerer et al., 2018).

In developed and developing countries, in addition to scientific and technological developments, it is a necessity that science education can be progressed sufficiently. For this reason, Science Technology Engineering Mathematics (STEM) education should be provided as a state policy in a qualified way in schools and in the curricula (Autenrieth et al., 2018; PCAST, 2010). STEM-based education system is important for countries that want to have a say in international development and adapt to scientific and technological developments (Tekerek \& Karakaya, 2018). Within the scope of STEM-based teaching activities, there are significant deficiencies in the development of teacher guide materials, in combination with the innovative technology addressing today's technology, in conducting teaching activities 
PROBLEMS

OF EDUCATION IN THE $21^{\text {st }}$ CENTURY Vol. 79, No. 5, 2021

752

and providing rich content teacher practices (Nadelson \& Seifert, 2017). In order to eliminate these deficiencies, applying to teaching practices in which researchers take an active role in all processes of teaching practices will increase the quality of teaching (Sadik, 2019).

Logger Pro is an interactive technology application with data collection and analysis, which are measured with advanced precision and sensitivity. In this context, application experiments are a regular part of physics lesson and laboratory education. It includes measuring instruments with sensors where experiments suitable for the curriculum can be designed, 100 measurements per second can be made and presented with tables and graphics, and the data obtained simultaneously can be transferred to word or Excel (Vernier, 2021). Logger Pro provides easy setup with the help of technological experimental measurements and automatic identification sensors. Data are presented in an understandable systematic form, as graphics, tables and text. Graphics and data tables can be printed at the level of significance (Firdaus et al., 2017; Supalo, 2014).

With the help of Logger Pro technology-supported experimental applications, physics, chemistry, and biology subjects with abstract content can be taught effectively (Supalo et al., 2007). In this context, preliminary stages of simulation-supported teaching in complex physics subjects such as dynamics, electricity, optics and magnetism are presented (Milner-Bolotin, 2016). In addition, the use of motion software has a practical function for computational modeling in physical materials such as visual representation of falling object movements, observing changes in the momentum of objects that are difficult to visualize directly, and motion with different speeds over time (Hechter, 2013). It provides visual representation of theoretical physics through computer software, making it easier for students to learn physics concepts. By making sense of concepts, it can reveal mathematical representations of knowledge and applications, graphical drawings, and simultaneous presentation of many variables (Whitworth et al., 2014; Yu et al., 2012).

When the concepts of hope and goal are examined separately; hope refers to positive expectation in achieving a goal related to the future, and goal refers to the net result determined to achieve that goal (Rideout \& Montemuro, 1986). Students should know that there are pathways to try to achieve their goals. Students encounter some obstacles in the process of achieving their success goals, and they need to be able to come up with systematic solutions and ways to overcome these obstacles. Otherwise, they stop hoping. Research results show that students with high levels of hope have higher perceptions that they can produce more alternative paths than low students (Snyder, 1999).

Science teaching basically consists of knowledge, skills and attitudes (Flick, 1993). The statement of attitude towards science and mathematics includes values, beliefs and feelings about science and mathematics, science and mathematics lessons at school, and the effects of science and mathematics on society (Rukavina et al., 2012). In the literature, it is pointed out that students' attitudes and interests towards science and mathematics develop before the age of 14 (Osborne \& Dillon, 2008). Considering that positive attitude towards science and mathematics is related to gaining positive experiences in the education process (Guzey et al., 2014) and students' attitudes may be determinant in their future career choices (Berlin \& White, 2010); it turns out that it is important to base on innovative technological applications in in-school and out-of-school science and mathematics applications. When the literature in this context is examined, it is of great importance to develop innovative technology-based methods and applications and to investigate their effects on the education process for quality science and mathematics education.

Positive attitude towards mathematics; it can be expressed as being interested in mathematics, volunteering in applications related to mathematics and wanting mathematics to take place in an important part of their life in the future (Farooq \& Shah, 2008). In meta-analysis examining mathematics attitudes (Hyde et al., 1990), a positive and reliable correlation was 
found between attitude towards mathematics and mathematics achievement. In recent years, the interest in mathematics-based professions has increased with the interest and attitude towards mathematics with innovative technology applications and mathematical modeling with STEM content (Baran et al., 2019).

Research literature shows those high school students' attitudes towards engineering content and the engineering professions are not at a positive level (Çevik, 2018). In particular, it is revealed that students with test anxiety do not have a positive attitude towards experimental applications and advanced drawing and engineering applications. There are very few studies on whether students' attitudes towards science and engineering have changed as a result of participating in engineering design activities in formal science classes (Tseng et al., 2013). There is a need to establish a theoretical and experimental framework for STEM education, which has become widespread in the Turkish education system, to meet both the goals of the Turkish Ministry of National Education and the hopes and goals of individuals, and to prepare an infrastructure for these goals. Thus, with STEM education, it will not only be a way of learning for students, but also a source of hope for their future lives; At the same time, it can be said that this education will set a target for achievement in school and attitude towards science as a lifestyle (Bybee, 2010). In this context, there is a need for experimental studies on the effects of the activities of high-school students enriched with advanced technological applications on their future course success, career choices, course, and professional attitudes in the content of science and mathematics courses.

In this study, the answers to the following questions were researched:

- Have there been any significant differences in students' STEM attitudes as a result of Logger Pro technology-supported experimental applications?

-What are the effects of Logger Pro technology-supported experimental applications on students' professional development and orientation?

-What are the effects of Logger Pro technology-supported experimental applications on the development of students' interdisciplinary skills?

\section{Research Methodology}

\section{General Background}

Action research was used to improve the effectiveness of the research process. The main purpose of action research is to develop solution suggestions together with all stakeholders in the environment where the problem is experienced and to share these suggestions with other teachers (Cohen et al., 2008; Yıldırım \& Şimşek, 2008). The results obtained in this context can be generalized to similar sample groups, but there is no concern about generalization to all events (Cohen et al., 2017). Action research is a type of systematic research applied in the classroom by actioner teachers based on their scientific knowledge and experience (Yildirım \& Şimşek, 2008). Researcher teachers can improve the quality and effectiveness of teaching practices by using action research (Walker, 1993). A well-planned action research by the researcher teacher can contribute to the professional development of the researcher and to better performing his role as a teacher (McNiff, Lomax \& Whitehead, 2010).

\section{Sample}

Within the scope of this study, while determining the sample of the research, the study was conducted with the student groups that the researcher attended the lectures throughout the term. The research was applied for six courses in two weeks in the fall semester of the 2019-2020 academic years. The research in Turkey, Mehmet Akif Ersoy High School in 


\section{Ahmet KUMAŞ. Evaluation of logger pro innovative technology supported applications in the scope of STEM}

PROBLEMS

OF EDUCATION

IN THE $21^{\text {st }}$ CENTURY Vol. 79, No. 5,2021

754

Trabzon Araklı was conducted with 84 students in Grade 10. The researcher made analysis by collecting systemic data aimed at understanding and solving the problems encountered during the implementation process by personally involving the applications in all processes of the research. Written permission was obtained from the school administration to collect the research data. The activities were based on voluntary participation. No comments, opinions or suggestions that could affect the opinions of the participants were made. Notes were taken during the interview by the researcher, but voice recordings were also taken, stating that it would not be used in another research and would not be named in order to prevent data loss. Before the interview form was recorded, it was confirmed by having the participants read it. The distribution according to the sample group and research type used in the study is shown in Table 1 .

Table 1

The Number of Students in the Research and Distribution by Groups

\begin{tabular}{lcccccccc}
\hline \multirow{2}{*}{ Gender } & $\begin{array}{c}\text { Rate } \\
(\%)\end{array}$ & \multicolumn{3}{c}{ Department Satisfaction } & \multicolumn{2}{c}{ Departments } & \multicolumn{2}{c}{ Interviews } \\
\cline { 3 - 8 } & & Satisfied & Dissatisfaction & Neutral & Science & Maths & Science & Maths \\
\hline $\begin{array}{l}\text { Male } \\
(N=39)\end{array}$ & 46 & 29 & 2 & 8 & 29 & 10 & 6 & 2 \\
\hline $\begin{array}{l}\text { Female } \\
(N=45)\end{array}$ & 54 & 36 & 4 & 5 & 33 & 12 & 9 & 3 \\
\hline Total $(84)$ & 100 & 65 & 6 & 13 & 62 & 22 & 20 \\
\hline
\end{tabular}

In the research process, the problems that may occur while providing teaching on illumination were determined by the action researcher during the application process and the process was analyzed by intervening the problems within the framework of the expertise of the researcher in order to minimize the problems that may arise in the learning environments.

\section{Data Collection}

Interview and questionnaire were used as data collection tools in the research. The first of these tools was semi-structured interviews (SSI), which was used to determine the effect of the action research application on the students' understanding of the subject, their application skills in the process and the effectiveness of STEM applications, and the second was the hope and goals questionnaire for STEM education adapted into Turkish by Yaman et al. (2019). The interview form was used to enable students to express themselves more easily in their natural environment with the language of communication and express their sincerity in their inner world. Within the scope of the study, a comprehensive literature review was carried out in order to ask questions that can overlap with the content. Support was received from four physics teachers and two Literature teachers in order to determine whether the content of the questions overlaps with the meaning content. The interview questions, which initially consisted of six questions, were restructured with the suggestions of six experts and reduced to four questions. These four questions are presented in the results section where the interview statements are presented. Within the scope of the study, the interviews were carried out after the end of the lessons, taking an average of thirteen minutes per person, based on student permission. The students in the study had a lot of free time to interview after the lessons were finished, as they were studying at a boarding school. 


\section{Data Analysis}

Content analysis was used in the analysis of the views of Logger Pro supported technological applications regarding students' future lives, career choices, other science courses and the development of mathematical processing skills. In this context, opinions with similar contents were brought together to provide readers with ease of reading and understanding (Smith, 2000). In order to provide a qualified content analysis, the inconsistencies in the description of the process were eliminated by comparing the audio recordings and the notes taken by the researcher. While reflecting the interview texts, statements that will best express the process are presented in writing to serve as an example. The coding and themes that best describe the process are divided into categories and presented in tables. Direct quotations were used in order to better reflect the contents of the study. Using the abbreviations while expressing the students, they were coded as S1, S2 ....S20.

The survey data were analyzed with SPSS 22.00 package program. Survey questions are rated between "1" and "5" values. During the six course hours, a process developed by an action researcher and supported by innovative technology was applied to application groups. The data in the test of hope and goals for STEM were analyzed using quantitative measurement techniques by structuring the teaching content of the application steps in content that could provide the learning content and provide gains. Within the scope of this study, Mills' (2003) action research systematic was adapted to the research group and students' attitudes and academic achievements were taken into account. This process is shown in table 2 .

\section{Table 2}

\section{STEM Compatible Action Research Process}

\begin{tabular}{ll}
\hline Stage & Studies Carried Out \\
\hline Data & $\begin{array}{l}\text { Innovative technology supported laboratory applications are presented to students by } \\
\text { using Logger Pro sensors. The data is obtained. }\end{array}$ \\
\hline Analysis & $\begin{array}{l}\text { The data obtained are interpreted according to physical and mental competence. } \\
\text { The data is shaped according to the readiness of the students and the environment. }\end{array}$ \\
\hline Implementation Plan & $\begin{array}{l}\text { The process is described in the light of the obtained data. } \\
\text { An action plan appropriate to the process is prepared. }\end{array}$ \\
\hline Reflection of the Process & $\begin{array}{l}\text { The planned learning process is associated with the situation encountered. } \\
\text { The problems between the planned process and the situation encountered are eliminated. }\end{array}$ \\
\hline Problem & $\begin{array}{l}\text { Problems in the application process are identified } \\
\text { Suggestions are made by the action researcher to solve the problems. }\end{array}$ \\
\hline
\end{tabular}

When the literature is examined in terms of validity and reliability for qualitative findings in action research, generally four categories recommended by Guba (1981) are used. These; it is credibility, transferability, dependability, and confirmability. In order to ensure credibility within the scope of the study, the relevant literature (Carr \& Kemmis, 2009; McAteer, 2013) was examined, the action researcher was a participant in the research environment for a long time, the process was described with continuous and uninterrupted observations, and experts and experienced colleagues were frequently asked to test the accuracy of opinions and facts. The data were diversified, sound recordings and documents were used. In order to ensure the transferability principles in action research, using the relevant literature (Finfgeld-Connett, 2010; Slevin \& Sines, 1999), the technological applications supported by Logger Pro are described 


\section{Ahmet KUMAŞ. Evaluation of logger pro innovative technology supported applications in the scope of STEM}

PROBLEMS

OF EDUCATION IN THE $21^{\text {st }}$ CENTURY Vol. 79 , No. 5, 2021

756

in detail and expressed in detail in the research report. Within the scope of the study, data diversification method was applied with the recommendations of the relevant literature (Guion et al., 2011) in order to ensure reliability, and by making group work with experts in their fields during and after the acquisition of the data, the interpretation of the data was ensured in a qualified manner. Within the scope of confirmability (Houghton et al, 2013), using the literature, data collection techniques were diversified, and the findings obtained were shaped with the assumptions of the action researcher by using the continuous participant feature that analyzes the accumulation and environment well. The quantitative findings of the study were based on the (Hopes and Goals Survey for K-12 STEM Education-SEHAG) data collection tool developed by Douglas \& Strobel (2015) and adapted into Turkish by (Yaman et al., 2019) by conducting a validity and reliability study. The final version of the study was applied in eighteen items. The SEHAG scale consists of four categories in total. These are, "learning and professional hope", "science attitude", "mathematics attitude" and "engineering attitude" categories. The reliability coefficient for the Explanatory Factor Analysis sample of the test, which was adapted to Turkish, was .86; The reliability coefficient for the Confirmatory Factor Analysis sample was found to be .87 (Yaman et al., 2019). The reliability level and consistency level of the scale used in the study is quite high.

\section{Logger Pro Technology Based Application}

The stages in the material developed for the illuminance subject in the optics unit by the teacher, the practitioner action researcher, for the students studying in the 10th grade in the physics lesson, were applied with Logger Pro support by taking into account table 3.

\section{Table 3}

Logger Pro Supported Application Example

\begin{tabular}{|c|c|c|c|}
\hline $\begin{array}{l}\text { Power Unit } \\
\text { Voltage (Volt) }\end{array}$ & $\begin{array}{c}\text { Measured light intensity } \\
\text { value lux (5 cm } \\
\text { distance) with Logger } \\
\text { Pro support }\end{array}$ & $\begin{array}{l}\text { Expressing } \\
\text { with a model }\end{array}$ & Evaluation of light intensity \\
\hline 0 & 0 & & Since the lamp is not lit, there is no light intensity \\
\hline 1.5 & 1200 & & $\begin{array}{l}\text { Since the lamp burns little, the lamp generates a } \\
\text { small amount of light. }\end{array}$ \\
\hline 3.0 & 2400 & & $\begin{array}{l}\text { Since the light intensity of the lamp increased, the } \\
\text { lamp gave a slightly stronger light. }\end{array}$ \\
\hline 4.5 & 3600 & & $\begin{array}{l}\text { Since the amount of light given by the lamp increases, } \\
\text { the light intensity also increased }\end{array}$ \\
\hline 6.0 & 4800 & & $\begin{array}{l}\text { Due to the large amount of light coming out of the } \\
\text { lamp, the light intensity is the highest }\end{array}$ \\
\hline
\end{tabular}

After making the Logger Pro supported applications in Table 4, students are expected to graphically show the relationship between the light intensity and the volt of the power unit and make their own drawings. The competence in technology-supported measurements should be associated with graphics at the analysis-synthesis level. The expected data to be obtained as a result of applications related to light intensity are shown in Figure 1. 


\section{Figure 1}

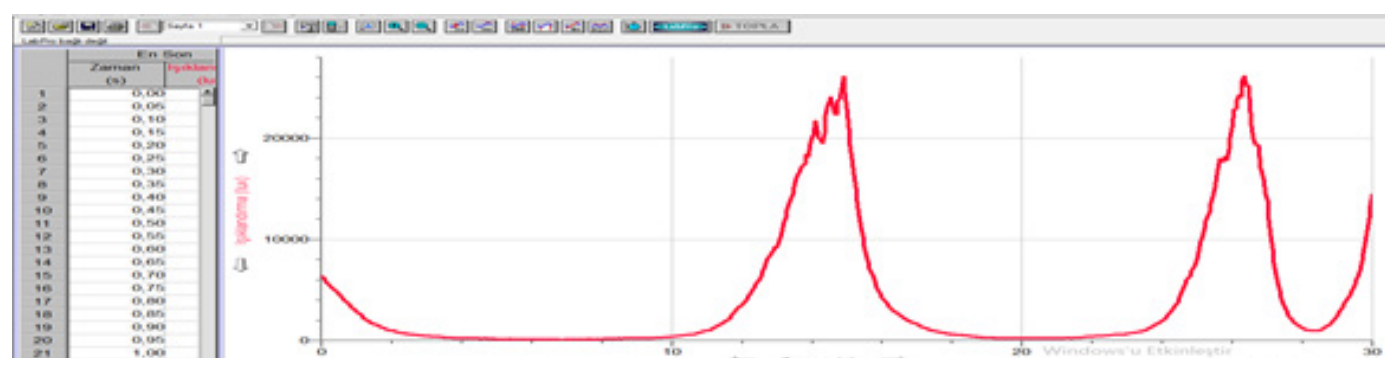

As can be seen in Figure 1, a certain part of the table obtained is shown. Since 20 measurements are made per second, there are 600 measurements in total. Part of the table is shown and the whole table is presented graphically. As a result of the measurements made from the same distance, it is seen that the light intensity increases regularly as the volt value is increased. The light intensity values expected to be measured on the screen by moving away from the light source without changing the volt value of the power unit by setting up a simple electrical circuit experiment setup are shown in Table 4.

\section{Table 4}

Measurement Results of Light Intensity Supported by Logger pro and Evaluation Data

$\begin{array}{lll}\begin{array}{l}\text { Distance from } \\ \text { light source } \\ (\mathrm{cm})\end{array} & \begin{array}{l}\text { Measured light intensity } \\ \text { value lux with Logger } \\ \text { Pro support (4,5 Volt) }\end{array} & \begin{array}{l}\text { Expressing } \\ \text { with a } \\ \text { model }\end{array}\end{array}$

As a result of the measurements in Table 4, from the students; As a result of Logger Pro technology-supported measurements, it is expected that the changes in light intensity depending on the distance change will be provided with the help of advanced technological tools that make 20 measurements per second, displayed by modeling and expressed verbally. 
PROBLEMS

OF EDUCATION IN THE $21^{\text {st }}$ CENTURY Vol. 79 , No. 5, 2021

758

\section{Research Results}

\section{Questionnaire Results}

Before performing one-way analysis of variance, homogeneity of variance test was examined for each subtest. There was no significant difference between the homogeneity of variances in the job satisfaction sub-dimension (Levene $\mathrm{F}$ statistics, $F_{(2-81)}=12.39, p>.05$ ). There were no significant differences between the homogeneities of the variances in the science (Levene $F$ statistics, $F_{(2-81)}=0.753, p>.05$ ), engineering (Levene $F$ statistic, $F_{(2-81)}=2.454, p>.05$ ) and the math attitude (Levene $F$ statistic, $F_{(2-81)}=1.241, p>.05$ ). According to these findings, it can be said that the variances at each level of the sub-factors are homogeneous.

Table 5

ANOVA Analysis Results According to the "Job satisfaction" Factor of Field Satisfaction

\begin{tabular}{|c|c|c|c|c|c|c|c|}
\hline STEM Sub-Factor & Content of Variance & $\begin{array}{l}\text { Sum of } \\
\text { Squares }\end{array}$ & $d f$ & $\begin{array}{l}\text { Average } \\
\text { Squares }\end{array}$ & $F$ & $p$ & $\begin{array}{l}\text { Significant } \\
\text { Difference }\end{array}$ \\
\hline \multirow{3}{*}{ Job Satisfaction } & Intergroup & 30.358 & 2 & 15.179 & 67.384 & .001 & $\begin{array}{l}A-B \\
C-B\end{array}$ \\
\hline & In-group & 18.246 & 81 & .225 & & & \\
\hline & Total & 48.604 & 83 & & & & \\
\hline \multirow{3}{*}{ Science Attitude } & Intergroup & 21.951 & 2 & 10.976 & 8.572 & .001 & $A-B$ \\
\hline & In-group & 103.715 & 81 & 1.280 & & & B-C \\
\hline & Total & 125.667 & 83 & & & & \\
\hline \multirow{3}{*}{$\begin{array}{l}\text { Engineering } \\
\text { Attitude }\end{array}$} & Intergroup & 6.216 & 2 & 3.108 & 2.102 & .129 & \multirow{3}{*}{--- } \\
\hline & In-group & 119.772 & 81 & 1.479 & & & \\
\hline & Total & 125.988 & 83 & & & & \\
\hline \multirow{3}{*}{ Math Attitude } & Intergroup & 39.950 & 2 & 19.975 & 88.068 & .001 & $A-B$ \\
\hline & In-group & 18.372 & 81 & .227 & & & C-B \\
\hline & Total & 58.321 & 83 & & & & \\
\hline
\end{tabular}

Note: A-B-C: Satisfaction status of the groups

According to Table 5, as a result of Logger Pro technology supported applications; a comparison is made between the students who chose their field voluntarily, did not choose voluntarily, or are undecided in high schools in the "job satisfaction" category in the scope of hope and goals within the scope of STEM $[F(2,81)=67,384, p<.01]$. As a result of the Tukey test analysis, students who chose their fields consciously and lovingly $(\bar{x}=4.78)$ compared to those who were not satisfied with their field $(\bar{X}=3.00)$; there were significant differences between the undecided $(\bar{X}=3.54)$ and the dissatisfied $(\bar{X}=2.780)$. These findings show that the adoption of the chosen field at the high school level has a positive effect on students' willingness and volunteering towards high-tech experiments and applications. Significant results were obtained in the "science attitude" category $[F(2.81)=8,643, p<.01]$. As a result of the Tukey test analysis, students who consciously and lovingly choose their fields $(\bar{X}=4.092)$ compared to those 
who were not satisfied with their field $(\bar{X}=3,500)$; there were significant differences between those who were not satisfied with their field $(\bar{X}=3.50)$ compared to those who were undecided $(\bar{X}=2.692)$. These findings show that the adoption of the chosen field at the high school level positively affects the students' willingness and volunteering towards the concepts, subjects, experiments, and daily life technological contents within the scope of science. In addition, in the case of field indecision, it is seen that STEM-based applications do not create positive attitudes towards science. There were no significant differences between group scores in the "engineering attitude" category $[F(2.81)=2.102, p>.01]$. This situation shows that engineering attitudes develop at the same level as a result of conducting STEM-contented applications with students who have voluntariness differences in their field preferences. There was a significant difference between the scores in the "mathematics attitude" category of the groups $[F(2.81)=88,068$, $p<.01]$. As a result of the Tukey test analysis, the group that was satisfied with the field $(\bar{X}$ $=4.692)$ compared to the group that was not satisfied $(\bar{X}=2.833)$; it is determined that the undecided ( $\bar{X}=3.154$ ) has significantly higher attitudes towards mathematical applications compared to the dissatisfied groups. This shows that STEM applications contribute significantly to the attitude and willingness of students who have a conscious choice of field in problems and applications with mathematical content that are difficult to understand and solve by students.

\section{Table 6}

T-test Data by "Gender" Factor as a Result of STEM Education

\begin{tabular}{|c|c|c|c|c|c|c|c|}
\hline STEM categories & Gender & $N$ & $\bar{x}$ & $S D$ & $d f$ & $t$ & $p$ \\
\hline \multirow{2}{*}{ Job Satisfaction } & $\mathrm{F}$ & 45 & 4.489 & .718 & \multirow{2}{*}{82} & \multirow{2}{*}{.391} & \multirow{2}{*}{.236} \\
\hline & $M$ & 39 & 4.423 & .823 & & & \\
\hline \multirow{2}{*}{ Science Satisfaction } & $\mathrm{F}$ & 45 & 3.911 & 1.311 & \multirow{2}{*}{82} & \multirow{2}{*}{.620} & \multirow{2}{*}{.398} \\
\hline & M & 39 & 3.744 & 1.141 & & & \\
\hline \multirow{2}{*}{$\begin{array}{l}\text { Engineering } \\
\text { Satisfaction }\end{array}$} & $\mathrm{F}$ & 45 & 2.089 & .6058 & \multirow[b]{2}{*}{82} & \multirow[b]{2}{*}{-8.028} & \multirow[b]{2}{*}{.001} \\
\hline & M & 39 & 3.718 & 1.196 & & & \\
\hline \multirow{2}{*}{ Math Satisfaction } & $\mathrm{F}$ & 45 & 4.378 & .912 & \multirow{2}{*}{82} & \multirow{2}{*}{.660} & \multirow{2}{*}{.176} \\
\hline & $M$ & 39 & 4.256 & .751 & & & \\
\hline
\end{tabular}

Note: $p<.05 ; \mathrm{F}$ : Female, M: Male

According to Table 6, as a result of Logger Pro innovative technology-supported STEM applications, $t$-test results of high school students by gender, job satisfaction $t(82)=.391, p>.05$, science approach $\mathrm{t}(82)=.620, p>.05$ and in the dimension of mathematics approach $t(82)=.660$, $p>.05$ didn't create a significant difference according to gender. There was a significant difference in favor of males in engineering approach $t(82)=8.028, p<.05$. 
Ahmet KUMAŞ. Evaluation of logger pro innovative technology supported applications in the scope of STEM

PROBLEMS

OF EDUCATION IN THE $21^{\text {st }}$ CENTURY Vol. 79 , No. 5, 2021

Table 7

T-Test Data According to the Field Factor Selected as a Result of STEM Education

\begin{tabular}{|c|c|c|c|c|c|c|c|}
\hline STEM categories & Department & $N$ & $\bar{x}$ & $S D$ & $d f$ & $t$ & $p$ \\
\hline \multirow{2}{*}{ Job Satisfaction } & Science & 45 & 4.573 & .751 & \multirow{2}{*}{82} & 2.359 & .939 \\
\hline & Math & 39 & 4.136 & .726 & & & \\
\hline \multirow{2}{*}{ Science Satisfaction } & Science & 45 & 4.419 & .713 & \multirow{2}{*}{82} & 12.258 & .0001 \\
\hline & Math & 39 & 2.182 & .795 & & & \\
\hline \multirow{2}{*}{$\begin{array}{l}\text { Engineering } \\
\text { Satisfaction }\end{array}$} & Science & 45 & 3.209 & 1.206 & \multirow{2}{*}{82} & 5.222 & .001 \\
\hline & Math & 39 & 1.818 & .524 & & & \\
\hline \multirow{2}{*}{ Math Satisfaction } & Science & 45 & 4.419 & .779 & \multirow{2}{*}{82} & 1.822 & .309 \\
\hline & Math & 39 & 4.045 & .950 & & & \\
\hline
\end{tabular}

$\overline{\mathrm{p}<.05}$

According to Table 7, as a result of Logger Pro innovative technology supported STEM content applications, $t$-test results of high school students in the "different field" category; job attitude $t(82)=2.359, p>.05$, and math attitude $t(82)=1.822, p>.05$ didn't make a significant difference. As a result of the education applied, there were significant differences in science attitude $t(82)=12,258, p<.05$, and engineering attitude $t(82)=5,222, p<.05$ in students whose field preferences are different. These significant differences were in favor of the science group.

$$
\text { Interview Results }
$$

Table 8

Classification of Interview Findings According to Answers

\begin{tabular}{lccc}
\hline Interview Question & Positive $(f)$ & Negative $(f)$ & Neutral $(f)$ \\
\hline Impact on future professional life & 19 & - & 1 \\
\hline Usage in other science classes & 20 & 7 & 2 \\
\hline $\begin{array}{l}\text { The effect on orientation to the engineering } \\
\text { profession }\end{array}$ & 11 & 7 & 5 \\
\hline $\begin{array}{l}\text { Effects on mathematical skills } \\
\text { Total (\%) }\end{array}$ & 8 & 17,5 & 10 \\
\hline
\end{tabular}

As seen in Table 8, according to the opinions of the participant students, the most positive effects of Logger Pro technology supported teaching applications are "use in other science classes" ( $f=20)$, "effect on future professional life" ( $f=19)$, "effect on orientation to the engineering profession" ( $f=11)$ and "its effect on mathematical skills" $(f=8)$. In the negativity category, answers were given in two fields. These were expressed as "its effect on orientation to the engineering profession" ( $f=7)$ and "its effect on mathematical skills" ( $f=7)$. Logger Pro emerged in the indecision category as the "effect of technology-supported teaching process on future professional life" ( $f=1)$, "effect on orientation to the engineering profession" $(f=2)$ and "effect on mathematical skills" $(f=5)$. To the participant students, "how useful do you see 
Logger Pro supported experimental tools in your future life?" The question has been posed. The important parts of the answers given are summarized below with the participants' own expressions. As an example of the answers given in the category of "positive answers", S11: "The experiment measurement tools we use while conducting experiments in the classroom are state-of-the-art tools. I will use them at the first opportunity as they are suitable for changing and developing technology", S3: "Actually, these technologies are used in all areas of our lives, and thanks to these experiments, we learned how to use advanced technological tools. I will definitely have to use it effectively in the future". S8: "No matter which profession I choose, technology based on sensors is necessary but not sufficient". S17: "I believe that meeting professionally advanced technology at an early age will make me more successful in my future profession. These measuring tools are indispensable in my future career". The answer given in the "indecisive" category was S2: "I do not know whether it will be beneficial or not, since I do not decide exactly which profession to choose".

To the participant students, "how do you evaluate the use of advanced technology experiments in other science lessons within the scope of STEM?" The question has been posed. The parts deemed important from the students' answers are summarized below with their own expressions. As an example of the answers given in the "positive answers" category, S5: "It will definitely be beneficial, we can make precise measurements in a short time, we can both make precise and clear measurements, and we can see the graphs by making measurements in a short time". S14: "Thanks to the measurements we made with sensors, our desire and love for science lessons have increased. Using it in other science lessons will help us approach all science lessons more positively". S7: "We will have observed the scientific origin of concepts in Chemistry and Biology with the latest scientific methods".

To the participant students, "do you need STEM applications to be a good engineer?" the question was asked. The parts deemed important from the students' answers are summarized below with their own expressions. As an example of the answers given in the category of "positive answers", S5: "My desire to become an engineer increased when I learned that such scientific measurement methods are used in engineering", S7: "Conducting experiments with precise and scientific measurements made me feel like an engineer, I think it will contribute to being a good engineer in the future". As an example of the answers given in the "negative answers" category, S13: "I had already determined my profession, these experiments and measurements did not have an effect on my choice of profession", S20: "A lot of attention is needed in experiments, I think a profession in the field of health". As an example of the answers given in the "neutral" category, S12: "The experiments and measurements are impressive, but I am still undecided about which profession to choose".

To the participant students, "do you believe that applications with STEM content are beneficial in increasing your math success?" the question was asked. As an example of the answers given by the students in the category of "Positivity", S5: "Now I saw that everything is related to mathematics, and these applications made me believe that I should focus more on mathematics". S19: "The application of mathematical modeling in physics with advanced technology experimental applications further strengthened the relationship between mathematics and physics in my mind". As an example of the answers given in the "negativity" category, S4: "I already knew that mathematics applications were necessary, these applications did not have an effect on my attitude towards mathematics necessity". As an example of the answers given in the "unstable" category, S10: "there is an inevitable relationship between mathematics and physics, I am unsure about the effects of these applications on my mathematical skills".

PROBLEMS
OF EDUCATION
IN THE 21 $1^{\text {st }}$ CENTURY
Vol. 79, No. 5, 2021 
PROBLEMS

OF EDUCATION

IN THE $21^{\text {st }}$ CENTURY Vol. 79, No. 5, 2021

762

\section{Discussion}

As a result of the laboratory applications with STEM content in the physics course, the job satisfaction of the students who consciously choose their field is higher. Students who make a conscious choice of field fulfill the responsibilities that are required by their own attitudes and orientations more effectively and demonstrate self-sacrificing works. Within the scope of the relevant literature (Stefanou et al., 2004), the fact that there are positive differences in the success and attitudes of the students who have developed a sense of autonomy in the decision-making process regarding the orientations related to their future coincide with the results of this study.

As a result of the laboratory applications with STEM content in the physics lesson, the science and mathematics attitudes of the students who consciously choose the field are higher. Considering that the contents within the scope of science and mathematics are empirical, measure-based and supportive of quantitative processing skills, it appears as a reason for students to contribute to the science and mathematics attitudes towards STEM teaching in case of education with advanced technological contents. The positive effectiveness of technology-supported applications in attitudes towards STEM within the scope of science and mathematics is also supported by the relevant literature (Ritz \& Fan, 2015; Wells, 2019).

As a result of the laboratory applications with STEM content in the physics course, the conscious choice of field has no effect on the engineering attitude. Considering that the engineering profession corresponds to a limited ratio among all professions, it is normal that there is no numerically significant difference. In Turkey, $90 \%$ of the students who excel in their school lessons are choosing professions in the health field. This result shows (Yorulmaz, 2019) in research that science students choose the health field the first corresponds to this result in research. When the teaching process in the laboratory applications in the physics course is carried out with Logger Pro technology-supported measurements with experimental content, the hopes and goals for STEM education according to "gender", it does not show a significant difference in job satisfaction, science attitude and mathematics attitude. Hopes and goals towards STEM education make a significant difference in favor of men in terms of engineering attitude. It can be shown as a reason to this situation that engineering profession in Turkey is a field preferred mostly by men. In (Ünlü \& Dökme, 2017) research studies, the fact that gifted students express the engineering profession as a male profession shows that men are more participatory in such activities.

Performing Logger Pro-supported measurements with technological content in schools improves the responsibility of students in homework, contributes to their successful graduation from high schools and to gain the departments they want in the university. These practices cause students to enjoy the profession they will choose in the future and help them reach their favorite profession by working harder. (Fan \& Yu, 2017) in their research; As a result of the STEM-oriented engineering design practices in Taiwan, it forms an integrity with the results of the research, in which they demonstrate the positive effects of high school students on their choice of profession and attitudes towards professions that require advanced technology.

In laboratories, as a result of technological supported applications, the hopes and goals of STEM education in all areas that students have chosen; it contributes to high school success in their course success, homework responsibilities, and getting into a good university in the future and have a profession they love. Since the mathematics course is a common and compulsory course in all academic fields, it contributes positively to the attitudes of all students. Since students with engineering orientation have to choose the academic field of science, these activities develop highly positive attitudes in science students in learning science and engineering subjects, in their orientation to the engineering profession and in their motivation to become a science teacher. In laboratories, using technological supported applications in mathematics 
lessons as well as physics, chemistry and biology lessons within the scope of science gives students positive professional and academic attitudes. Graphical interpretations at the analysis synthesis level and mathematical operations and problem solutions at the stages of determining the relationship between prediction and result contribute partially to the development of students' mathematical processing skills.

\section{Conclusions and Implications}

Considering the positivity in terms of mathematical operation skills and mathematical attitude in the research results, in experimental applications supported by Logger Pro; Even if the students make mistakes, it will be useful to follow the systematic that will support the STEM content, considering that it will be beneficial in terms of contributing to the responsibility and self-confidence of the students. Since students' adaptation of the information they have learned to a new situation in daily life is considered an advanced learning activity, it will be beneficial to provide individual and group support to student groups during the experimental applications supported by Logger Pro. Considering the Logger Pro technology-supported application orientations in other science lessons in the research results; while applying the STEM process, if it is an interdisciplinary subject, interacting with teachers in the same course and with other science and mathematics teachers will contribute positively to the process. The implementation of Logger Pro-supported technological activities in all schools consisting of financially disadvantaged groups will contribute to providing equal opportunity to students. Before the application, it will be useful to shape the contents of the activities by conducting an interest-attitude questionnaire in order to emphasize the daily life problems of the students in experimental applications supported by Logger Pro.

\section{References}

Autenrieth, R., Lewis, C., \& Butler-Purry, K. (2018). Enrichment experiences in engineering (E3) summer teacher program: Analysis of student surveys regarding engineering awareness. Journal of STEM Education: Innovations and Research, 19(4), 19-29.

Aydoğdu, B., Buldur, S., \& Kartal, S. (2013). The effect of open-ended science experiments based on scenarios on the science process skills of the pre-service teachers. Procedia-Social and Behavioral Sciences, 93, 1162-1168. https://doi.org/10.1016/j.sbspro.2013.10.008

Baran, E., Canbazoglu Bilici, S., Mesutoglu, C., \& Ocak, C. (2019). The impact of an out-of-school STEM education program on students' attitudes toward STEM and STEM careers. School Science and Mathematics, 119(4), 223-235. https://doi.org/10.1111/ssm.12330

Berlin, D. F., \& White, A. L. (2010). Preservice mathematics and science teachers in an integrated teacher preparation program for grades 7-12: A 3-year study of attitudes and perceptions related to integration. International Journal of Science and Mathematics Education, 8(1), 97-115. https://doi.org/10.1007/s10763-009-9164-0

Bybee, R. W. (2010). Advancing STEM education: A 2020 vision. Technology and engineering teacher, 70(1), 30. https://doi.org/10.1126/science. 1194998

Camerer, C. F., Dreber, A., Holzmeister, F., Ho, T. H., Huber, J., Johannesson, M., ... \& Wu, H. (2018). Evaluating the replicability of social science experiments in Nature and Science between 2010 and 2015. Nature Human Behaviour, 2(9), 637-644. https://doi.org/10.1038/s41562-018-0399-z

Carr, W., \& Kemmis, S. (2009). Educational action research: A critical approach. The Sage handbook of educational action research, 74-84. https://dx.doi.org/10.4135/9780857021021.n8

Cohen, D. J., \& Crabtree, B. F. (2008). Evaluative criteria for qualitative research in health care: controversies and recommendations. The Annals of Family Medicine, 6(4), 331339. https://doi.org/10.1370/afm. 818

Cohen, L., Manion, L., \& Morrison, K. (2017). Action research. In Research methods in education (pp. 440-456). Routledge. https://doi.org/10.4324/9781315456539

\author{
PROBLEMS \\ OF EDUCATION \\ IN THE $21^{\text {st }}$ CENTURY \\ Vol. 79, No. 5, 2021 \\ 763
}


PROBLEMS

OF EDUCATION IN THE $21^{\text {st }}$ CENTURY Vol. 79, No. 5, 2021

764

Çevik, M. (2018). Impacts of the project based (PBL) science, technology, engineering and mathematics (STEM) education on academic achievement and career interests of vocational high school students. Pegem Eğitim ve Öğretim Dergisi, 8(2), 281-306, http://dx.doi.org/10.14527/pegegog.2018.012

Douglas, K. A., \& Strobel, J. (2015). Hopes and Goals Survey for use in STEM elementary education. International Journal of Technology and Design Education, 25(2), 245-259. https://doi.org/10.1007/s10798-014-9277-9

Fan, S. C., \& Yu, K. C. (2017). How an integrative STEM curriculum can benefit students in engineering design practices. International Journal of Technology and Design Education, 27(1), 107-129. https://doi.org/10.1007/s10798-015-9328-x

Farooq, M. S., \& Shah, S. Z. U. (2008). Students' attitude Towards Mathematics. Pakistan Economic and Social Review, 75-83.

Finfgeld-Connett, D. (2010). Generalizability and transferability of meta-synthesis research findings. Journal of advanced nursing, 66(2), 246-254. https://doi.org/10.1111/j.1365-2648.2009.05250.x

Firdaus, T., Setiawan, W., \& Hamidah, I. (2017, September). The Kinematic Learning Model using Video and Interfaces Analysis. In Journal of Physics: Conference Series, 895(1), 012108. https://doi.org/10.1088/1742-6596/895/1/012108

Flick, L. B. (1993). The meanings of hands-on science. Journal of Science Teacher Education, 4(1), 1-8. https://doi.org/10.1007/BF02628851

Guba, E. G. (1981). Criteria for assessing the trustworthiness of naturalistic inquiries. Ectj, 29(2), 75-91. https://doi.org/10.1007/BF02766777

Guion, L. A., Diehl, D. C., \& McDonald, D. (2011). Triangulation: Establishing the validity of qualitative studies. EDIS, 2011(8), 3-3.

Guzey, S. S., Harwell, M., \& Moore, T. (2014). Development of an instrument to assess attitudes toward science, technology, engineering, and mathematics (STEM). School Science and Mathematics, 114(6), 271-279. https://doi.org/10.1111/ssm.12077

Hechter, R. P. (2013). Hockey, iPads, and projectile motion in a physics classroom. The Physics Teacher, 51(6), 346-347. https://doi.org/10.1119/1.4818370

Houghton, C., Casey, D., Shaw, D., \& Murphy, K. (2013). Rigour in qualitative case-study research. Nurse researcher, 20(4). https://doi.org/10.7748/nr2013.03.20.4.12.e326

Hyde, J. S., Fennema, E., Ryan, M., Frost, L. A., \& Hopp, C. (1990). Gender comparisons of mathematics attitudes and affect: A meta-analysis. Psychology of women quarterly, 14(3), 299-324. https://doi.org/10.1111/j.1471-6402.1990.tb00022.x

Jackson, S. A., \& Schmidt, E. (2010). President's Council of Advisors on Science and Technology (PCAST) President's Innovation and Technology Advisory Committee (PITAC) Golden Triangle Workshop June 22, 2010.

Linn, M. (2003). Technology and science education: starting points, research programs, and trends. International Journal of Science Education, 25(6), 727 758. https://doi.org/10.1080/09500690305017

McAteer, M. (2013). Action research in education. Sage.

McNiff, J. (2016). You and your action research project. Routledge.

Mills, G. E. (2003). Action research: A guide for the teachers researcher. Merrill/Prentice Hall.

Milner-Bolotin, M. (2016). Rethinking technology-enhanced physics teacher education: From theory to practice. Canadian Journal of Science, Mathematics and Technology Education, 16(3), 284-295. https://doi.org/10.1080/14926156.2015.1119334

Nadelson, L. S., \& Seifert, A. L. (2017). Contexts, challenges, and the future, The Journal of Educational Research, 110(3), 221-223. https://doi.org/10.1080/00220671.2017.1289775

Osborne, J., \& Dillon, J. (2008). Science education in Europe: Critical reflections. A Report to the Nuffield Foundation, 13. London: The Nuffield Foundation. http://efepereth.wdfiles.com/localfiles/ scienceeducation/Sci_Ed_in_Europe_Report_Final.pdf

PCAST (2010). President's Council of Advisors on Science and Technology (PCAST. Prepare and inspire: K-12 education in science, technology, engineering, and math (STEM) for America's future. Author.

Rideout, E., \& Montemuro, M. (1986). Hope, morale and adaptation in patients with chronic heart failure. Journal of Advanced Nursing, 11(4), 429-438. https://doi.org/10.1111/j.1365-2648.1986. tb01270.x 
Ritz, J. M., \& Fan, S. C. (2015). STEM and technology education: International state-ofthe-art. International Journal of Technology and Design Education, 25(4), 429-451. https://doi.org/10.1007/s10798-014-9290-z

Rukavina, S., Zuvic-Butorac, M., Ledic, J., Milotic, B., \& Jurdana-Sepic, R. (2012). Developing positive attitude towards science and mathematics through motivational classroom experiences. Science education international, 23(1), 6-19. https://files.eric.ed.gov/fulltext/EJ975543.pdf

Sadik, O. (2019). Critical Participatory Action Research: A Design to Empower Women in a Teacher Education Institution. International Journal of Research in Teacher Education, 10(2), 20-27. https://ijrte.penpublishing.net/makale_indir/927

Slevin, E., \& Sines, D. (1999). Enhancing the truthfulness, consistency and transferability of a qualitative study: utilizing a manifold of approaches. Nurse Researcher (through 2013), 7(2), 79.

Smith, C. P. (2000). Content analysis and narrative analysis. In H. T. Reis \& C. M. Judd (Eds.), Handbook of research methods in social and personality psychology (pp. 313-335). Cambridge University Press.

Snyder, C. R. (1999). Hope, goal-blocking thoughts, and test-related anxieties. Psychological Reports, 84(1), 206-208. https://doi.org/10.2466/pr0.1999.84.1.206

Stefanou, C. R., Perencevich, K. C., DiCintio, M., \& Turner, J. C. (2004). Supporting autonomy in the classroom: Ways teachers encourage student decision making and ownership. Educational Psychologist, 39(2), 97-110. https://doi.org/10.1207/s15326985ep3902_2

Supalo, C. A., Mallouk, T. E., Amorosi, C., Rankel, L., Wohlers, H. D., Roth, A., \& Greenberg, A. (2007). Talking Tools to Assist Students Who Are Blind in Laboratory Courses. Journal of Science Education for Students with Disabilities, 12(1), 27-32. https://files.eric.ed.gov/fulltext/ EJ1169422.pdf

Supalo, C. A., Mallouk, T. E., Dwyer, D., Eberhart, H. L., \& Bunnag, N. W. (2014). Teacher training workshop for educators of students who are blind or low vision. Journal of Science Education for Students with Disabilities, 13(1), 3.

Tekerek, B., \& Karakaya, F. (2018). STEM education awareness of pre-service science teachers. International Online Journal of Education and Teaching, 5(2), 348-359. http://iojet.org/index. $\mathrm{php} / \mathrm{IOJET} / \mathrm{article} / \mathrm{view} / 310 / 239$

Tseng, K. H., Chang, C. C., Lou, S. J., \& Chen, W. P. (2013). Attitudes towards science, technology, engineering and mathematics (STEM) in a project-based learning (PjBL) environment. International Journal of Technology and Design Education, 23(1), 87-102.

Ünlü, Z. K., \& Dökme, İ. L. B. İ. L. G. E. (2017). Özel yetenekli öğrencilerin FeTeMM'in mühendisliği hakkındaki imajları [Gifted children' images about STEM's E]. Trakya Üniversitesi Eğitim Fakültesi Dergisi, 7(1). https://dergipark.org.tr/en/pub/trkefd/issue/27304/287435

Vernier (2021). Vernier Computer Interface Logger Pro, 18 January 2021.

Walker, M. L. (1993). Participatory action research. Rehabilitation Counseling Bulletin, 37, 2-2.

Wells, J. G. (2019). STEM education: The potential of technology education. Council on Technology and Engineering Teacher Education.

Whitworth, B. A., Chiu, J. L., \& Bell, R. L. (2014). Kinesthetic investigations in the physics classroom. The Physics Teacher, 52(2), 91-93. http://dx.doi.org/10.1119/1.4862112

Yaman, S., Tungaç, A. S., \& İncebacak, B. B. (2019). STEM eğitimine yönelik umut ve hedefler ölçeği uyarlaması: geçerlik ve güvenilirlik çalışması [Adaptation of hopes and goals survey for STEM education: Validity and reliability study]. Kastamonu Ĕgitim Dergisi, 27(3), 1273 1290. http://dx.doi.org/10.24106/kefdergi.3022

Yıldırım, A., \& Şimşek, H. (2008). Sosyal Bilimlerde Nitel Araştırma Yöntemleri [Qualitative research methods in the social sciences]. Seçkin Yayıncılık.

Yorulmaz, M. (2019). Sağlık Yönetimi Bölümü Öğrencilerinin Bölümü Tercih Etme Nedenlerinin İncelenmesi [Investigation of reasons for the preference of health management department students]. Selçuk Üniversitesi Sosyal Bilimler Meslek Yüksekokulu Dergisi, 22(1), 74-82. https://doi.org/10.29249/selcuksbmyd.506880

Yu, Y., Wen, M. W., \& Fang, K. (2012). Kinematics experiment analyzed with Logger pro3.6. 0 software [J]. Physics Experimentation, 10.

$\mid \begin{aligned} & \text { PROBLEMS } \\ & \text { OF EDUCATION } \\ & \text { IN THE } 21^{\text {st }} \text { CENTURY } \\ & \text { Vol. 79, No. 5, } 2021\end{aligned}$

765 
Ahmet KUMAŞ. Evaluation of logger pro innovative technology supported applications in the scope of STEM

PROBLEMS

OF EDUCATION

IN THE $21^{\text {st }}$ CENTURY

Vol. 79, No. 5, 2021

Received: July 06, 2021

Accepted: October 06, 2021

Cite as: Kumaş, A. (2021). Evaluation of logger pro innovative technology supported applications in the scope of STEM. Problems of Education in the 21st Century, 79(5), 751766. https://doi.org/10.33225/pec/21.79.751

Ahmet Kumaş $\quad$ PhD, Lecturer, Uşak University, Ankara Izmir Karayolu 8, Km. 1 Eylul Kampusu, 64200 Usak, Turkey.

E-mail: ahmetkumas_61@hotmail.com

ORCID: https://orcid.org/0000-0002-2898-9477 